\title{
The Danger of Toxic Substances
}

Toxic (harmful) gases enter building interiors partly from outdoors (sulfur oxides, nitrogen oxides, carbon monoxide, ozone, smog and acid rains), partly originate indoors - as a result of human activity (carbon monoxide, tobacco smoke, nitrogen oxides, ozone, hydrocarbons) and also emanate from building materials (formaldehyde, volatile organic compounds). The human organism is most often exposed to cigarette smoke (especially nonsmokers are endangered, as cigarette smoke devastes the pulmonary and cardiovasculary system) and to smog entering from outdoors, paradoxically during sunny weather. Preventing toxic production is the most effective measure, e.g., by coaxing to coax smokers out of "civilized" areas, by using energy rationally (i.e., conserving energy), to turn to pure fuels and to increase energy production by non-combustion technologies. Besides ventilation and air filtration, the toxic gases can be removed to a remarkable extent by plants (by which decay the substances into nontoxic gases), and by air ionization. Review article.

Keywords: toxic substances, hygienic problem of buildings, health problem within buildings, sick building syndrome.

Gaseous toxic agents occurring in the interior of a building and affecting the total state of the human organism form a constituent of the microenvironment, known as the toxic microclimate [3], [10]. Odor agents in higher concentrations may also be harmful, but some toxic agents in any concentration do not smell at all (e.g., carbon monoxide).

\section{Sources of Toxic Gases}

The components of the toxic microclimate are toxic gases, i.e., gaseous components of the atmosphere which produce pathological changes in an exposed subject. There are organic and inorganic gases. They either enter the interior from the outdoor atmosphere or they occur within the building, produced by human activity, or released from building materials [6], [7], [8].

\subsection{Outdoor Air as a Source of Toxic Substances}

From the outdoor atmosphere, toxics enter the interior: carbon monoxide, sulfur dioxide and trioxide, oxides of nitrogen, ozone, some hydrocarbons and especially smog and acid rains (Fig. 1) in recent times.

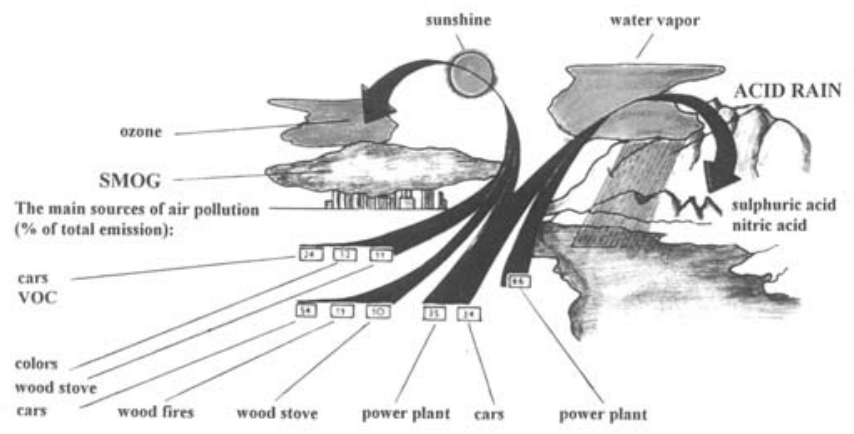

Fig. 1: The main sources of air pollution outdoors, smog and acid rain formation (production of harmful agent as a percentage of total emission in windows)

Carbon monoxide $\mathrm{CO}$ is produced mainly in gasoline engines and by boiler furnaces and stoves with imperfect (incomplete) combustion. Its affinity with building materials is very slow and its concentration decreases very slowly in an unventilated room (just by diffusion).
Sulfur dioxide $\mathrm{SO}_{2}$ and sulfur trioxide $\mathrm{SO}_{3}$ are produced by burning fossil fuels containing sulfur. Combined with water, acids are produced (e.g., concentrated sulphuric acid $\mathrm{H}_{2} \mathrm{SO}_{4}$ ). The concentration of sulfur dioxide decreases rapidly in rooms with lime plaster and usual furniture, if there is ventilation by infiltration (air change by untight windows, doors and walls). Just one hour after windows are closed, no concentration can be measured. But after windows were opened, the indoor sulfur dioxide concentration equaled the outdoor concentration within a few minutes. In airconditioned rooms, the sulfur dioxide concentrations are maintained indoors at 30 to $40 \%$ of the outdoor concentrations.

Oxides of nitrogen $\mathbf{N O}_{\mathbf{x}}$ are produced from atmospheric nitrogen by high burning temperatures. Diesel engines, boiler houses in power stations and industrial plants, and the operation of gas appliances. They can be combined with various building materials within the interior, thus the concentration of these oxides decreases rapidly, if there is ventilation by infiltration only.

Complexes of these agents form so called acid rains during rainy weather and so called smog during sunny weather, by the following process.

Oxides of nitrogen and oxides of sulfur mixed with other natural chemicals (water vapor) form acids in higher levels of the atmosphere, and fall as acid rain (Fig. 1). These rains, known to be dangerous for forests, also have a negative effect on building structures.

Smog (smoke + fog from oxides of nitrogen and other harmful agents, not from water vapor) is a result of air pollution: nitrogen dioxide $\mathrm{NO}_{2}$ mixed with carbon monoxide and water vapor by an intensive UV radiation impact is decayed into nitrogen monoxide $\mathrm{NO}$ and very reactive atomic oxygen $\mathrm{O}$. Atomic oxygen $\mathrm{O}$ bonded with molecular oxygen $\mathrm{O}_{2}$ forms ozone $\mathrm{O}_{3}$. Additional toxic gases are also produced by these photochemical processes (photochemical smog) e.g., compounds of peroxoacetyl (PANs), aldehydes and organic acids. These gases are produced from hydrocarbons, e.g., from methane, ethane, ethylene, propane or butane, forming about one third of photochemical smog. The remaining smog contains ozone and CO. Intensive UV radiation is a condition for smog formation: thus the smog concentration increases towards midday and decreases later in the afternoon and in 
the morning. High relative humidity disturbes UV radiation penetration, and thus also smog formation (it decreases almost to zero at $r h=75 \%$ ). Indoor ozone concentration is usually about a half of the outdoor ozone concentration.

Lightning is the most common source of ozone. It is combined with oxidizable organic materials in the interior. Thus, if there is no supply of air with ozone, the ozone concentration decreases exponentially (i.e., very rapidly) below $20 \%$ of the original (starting) value within 30 minutes. The decrease is faster in rooms with rubber, plastic and textile surfaces than in interiors with metal and glass surfaces. No differences were found between apartments with gas and electric kitchens (from a theoretical point of view, faster decay of ozone may be supposed in a room with gas appliances).

Vehicles (smoke from vehicle engines, evaporation from fuel tanks) and the chimneys of furnaces with incomplete combustion are the main sources of hydrocarbons.

\subsection{Indoor Sources of Toxics}

Toxic substances in building interiors are produced by human activity and are released from building materials.

Carbon monoxide, due to human activity, is the most common component of the toxic microclimate. The sources are usually internal combustion engines (up to $7 \% \mathrm{CO}$ when idling), cigarette smoking, various stoves and boilers. During complete combustion smoke contains about 0.2 to $0.5 \% \mathrm{CO}$; during incomplete combustion, the percentage is substantially higher. City gas piping may be a source of carbon monoxide. CO concentrations were measured inside kitchens and living rooms during nonsummer months: inside more than $6 \%$ of the apartments it was over 10 ppm (12 000 $\left.\mu \mathrm{g} / \mathrm{m}^{3}\right)$, and even up to $60 \mathrm{ppm}\left(70000 \mu \mathrm{g} / \mathrm{m}^{3}\right)$ within locally heated rooms. These values are not toxic, but long-term exposure may cause an increase in accidents, and may affect the overall state of the human organism. The main reasons for high carbon monoxide concentrations are an insufficient air supply (unsuitable location of inlets or blocked inlets), partially blocked injectors of gas burners, leaky combustion chambers, unsuitable fuel in stoves, and leaky chimneys in old buildings.

Oxides of nitrogen, apart from carbon monoxide, are also emitted by gas appliances. The concentration of nitrogen dioxide may be higher by about $50 \mu \mathrm{g} / \mathrm{m}^{3}$ within kitchens and about 20 to $25 \mu \mathrm{g} / \mathrm{m}^{3}$ in bedrooms than in the outdoor air (about $10 \mu \mathrm{g} / \mathrm{m}^{3}$ ). The nitrogen dioxide concentrations were about $5 \mu \mathrm{g} / \mathrm{m}^{3}$ higher within buildings where propane was used than in houses with natural gas, as a result of different gas compositions. There was even a lower nitrogen dioxide concentration in electrical kitchens (about $6 \mu \mathrm{g} / \mathrm{m}^{3}$ ) than outdoors - probably as a result of increased air infiltration into the kitchens. Therefore a gas cooker is a worse source of nitrogen dioxide than exhaust fumes from cars coming from outdoors.

Dangerous ozone concentrations may be reached during long-term operation of artificial sunlight (solarium) inside a room: this is produced by the impact of UV radiation on air molecules.

Photocopiers and laser printers are the most frequent source of ozone nowadays: they produce about $100 \mu \mathrm{g} / \mathrm{min}$ $(20-1350 \mu \mathrm{g} / \mathrm{min})$ of ozone. These emissions can cause an ozone concentration of $200 \mathrm{ppb}\left(400 \mu \mathrm{g} / \mathrm{m}^{3}\right)$ in a badly ventilated room.

The main sources of hydrocarbons indoors, besides gas and oil appliances, are various detergents, insecticides, pesticides, herbicides, impregnants, preservatives, fungicides, etc. They are also produced by tobacco smoking.

Formaldehyde, styrene, and various organic agent mixtures may be released from building materials. Building elements (wood fiber plates, chipboards, sawdust boards, insulation boards) made from granulated organic raw materials and joined with ureaformaldehyde and phenolformaldehyde adhesives are very often sources of formaldehyde, as are some plastics, varnishes, enamels and lacquers. Formaldehyde may also be released from finishing agents in textiles; during incomplete fuel combustion, it is present in tobacco smoke and is an intermediate compound of the photochemical oxidation of hydrocarbons in the atmosphere. Formaldehyde is also used in the cosmetics industry as an antihydroticum (antihydrating agent) and in medical care as a disinfectant (bactericide agent) and antimycoticum (fungicide agent) [2].

Some other toxic substances may be released from plastics inside a room: styrene from polystyrene, mixtures of organic gases from coatings (especially if heated). Decay products of various materials are listed in Table 1.

Table 1: Decay products of various building materials

\begin{tabular}{|c|c|c|c|c|c|c|c|c|c|c|c|c|c|c|c|}
\hline \multirow[b]{2}{*}{ Decay product } & \multirow{2}{*}{ Material } & 1 & 2 & 3 & 4 & 5 & 6 & 7 & 8 & 9 & 10 & 11 & 12 & 13 & 14 \\
\hline & & & & & & & & & & & & & & & \\
\hline $\mathrm{CO}$ & & + & + & + & + & + & + & + & + & + & + & + & + & + & + \\
\hline $\mathrm{CO}_{2}$ & & + & + & + & + & + & + & + & + & + & + & + & + & + & + \\
\hline $\mathrm{H}_{2} \mathrm{O}$ & & + & + & + & + & + & + & + & + & + & + & + & + & + & + \\
\hline lower hydrocarbons & & + & & & & & & & & & & & & & \\
\hline aldehydes & & + & & & & & & & & & & & & & \\
\hline lower acids & & + & & & & & & & & & & & & & \\
\hline higher flavoring & & & + & & & & & & & & & & & & \\
\hline mono-tetra styrene & & & + & & & & & + & & & & & & & \\
\hline
\end{tabular}




\begin{tabular}{|c|c|c|c|c|c|c|c|c|c|c|c|c|c|c|}
\hline \multirow[b]{2}{*}{ Decay product } & 1 & 2 & 3 & 4 & 5 & 6 & 7 & 8 & 9 & 10 & 11 & 12 & 13 & 14 \\
\hline & & & & & & & & & & & & & & \\
\hline soot & & + & + & + & & & & & & & & & & \\
\hline $\mathrm{HCl}$ & & & + & + & & & & & & & & & & \\
\hline phosgene & & & + & + & & & & & & & & & & \\
\hline $\mathrm{Cl}_{2}$ & & & + & + & & & & & & & & & & \\
\hline chlorohydrocarbons & & & + & + & & & & & & & & & & \\
\hline methacrylic acid ester & & & & & + & & & & & & & & & \\
\hline saturated esters & & & & & + & & & & & & & & & \\
\hline acrylonitrile & & & & & & + & & & & & & & & \\
\hline $\mathrm{NH}_{3}$ & & & & & & + & & & & & & & & \\
\hline $\mathrm{HCN}$ & & & & & & + & & & + & & & & & + \\
\hline higher boiling compounds of $\mathrm{N}$ & & & & & & + & & & & + & + & + & & + \\
\hline formaldehyde & & & & & & & + & & & & & & + & \\
\hline formic acid & & & & & & & + & & & + & & & + & \\
\hline phenol & & & & & & & + & & & & & & & \\
\hline amines & & & & & & & & & & + & + & + & & \\
\hline cyanates & & & & & & & & & & & & + & & \\
\hline isocyanates & & & & & & & & & & & & + & + & \\
\hline methanol & & & & & & & & & & & & & & \\
\hline acetic acid & & & & & & & & & & & & & + & \\
\hline $\mathrm{H}_{2} \mathrm{~S}$ & & & & & & & & & & & & & & + \\
\hline ethylbenzene & & + & & & & & & & & & & & & \\
\hline
\end{tabular}

1 - polyolefins

2 - polystyrene

3 - PVC

4 - PVC softened

5 - methyl methacrylate

6 - acrylonitrile

7 - phenol resins

Teflon, used in pots and pans, can serve as an example. Teflon decays when warmed to temperatures of about 100-150 ${ }^{\circ} \mathrm{C}$ higher than the usual temperatures for baking and frying. Irritating and harmful gases are produced. For this reason pots and pans with a teflon layer should not be heated when empty, without food. Smoking during teflon processing is also not allowed because the glowing end of a cigarette decays teflon dust, and inhaling the smoke that is produced causes an illness known as "polymer fever". The dangers of using teflon start at temperatures over about $260{ }^{\circ} \mathrm{C}$ (depending on the type of teflon).

Formaldehyde, various hydrocarbons, toluene, benzene and other agents, released from various materials in a building interior, are referred to, jointly, as volatile organic compounds or chemicals, VOCs. VOCs in higher concentrations are harmful, of course [4], [5], [6]. The application of cyanoacrylate adhesives can also be dangerous. They cause eye irritation, asthma and skin diseases in $1.4 \%$ of the population (predominantly women) according to the Finnish Institute of Occupational Health.

$$
\begin{aligned}
& 8 \text { - polyesters } \\
& 9 \text { - epoxides } \\
& 10 \text { - melanine resins } \\
& 11 \text { - polyamides } \\
& 12 \text { - polyurethanes } \\
& 13 \text { - wool } \\
& 14 \text { - wool, silk }
\end{aligned}
$$

Tobacco smoke must also be considered toxic, as proved by recent research. The human organism is also seriously threatened by smoke produced by other people, by so called Environmental Tobacco Smoke, ETS.

\section{Impact of toxic gases on the human organism}

Toxic strain depends on the kind of toxic agent (noxa) each one usually has a specific impact on the human body (Fig. 2).

The most common noxa - carbon monoxide - affects subjects in two ways:

a) By an affinity to hemoglobin (200 to 300 times higher than to oxygen) and forming carbonyl hemoglobin (COHb). The consequence is hypoxemia and hypoxia: the hemoglobin is not able to transfer oxygen. Even the remaining oxyhemoglobin is unable to deliver oxygen to the tissues. 


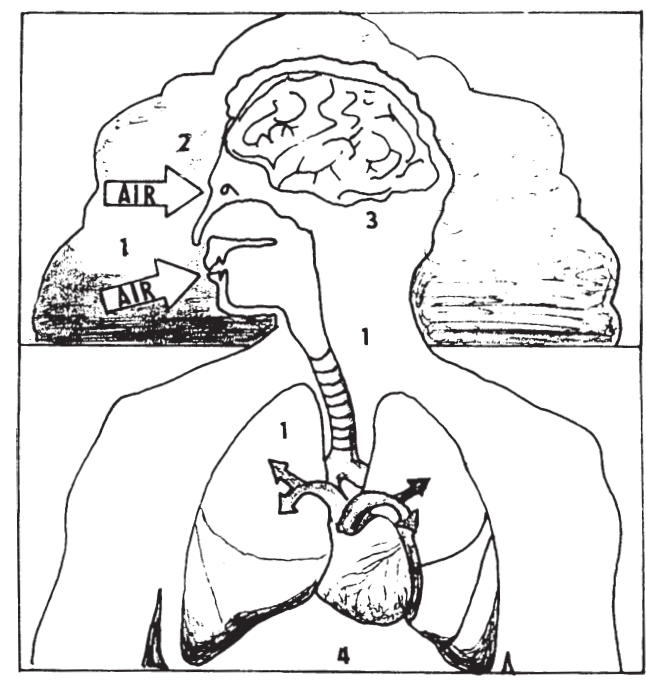

Fig. 2: Impact of a toxic agent on the human organism (air=exposing air, 1 nose, throat, lungs: inhaled ozone decreases the resistance of the lungs to infection, making asthma worse, 2 eyes: formaldehyde and peroxyacetylnitrate irritate eyes, 3 brain: inhaling $\mathrm{CO}$ can decrease motion coordination and the ability to concentrate, probably as a result of decreased oxygen delivery to the brain, 4 heart: $\mathrm{CO}$ decreases oxygen delivery; low oxygen concentration in the blood exacerbates angina pectoris - pains in the chest).

b) By blocking respiration fragments (cytochromoxidases): cells of these tissues are toxically damaged and the impact of hypoxia is increased. E.g., an eight hour stay in air with a concentration of $90 \mathrm{mg} / \mathrm{m}^{3}$ has the same effect on the human organism as the loss of one liter of blood. The consequence of poisoning of the human body by $\mathrm{CO}$ is headache, loss of coordination, loss of concentration and even apathy, pains throughout the body sometimes changing into cramps, loss of consciousness and even death [9].

Poisonings are classified as: light (short, several minutes of unconsciousness), medium heavy ( 1 to 4 hours of unconsciousness) and very heavy (over 8 hours of unconsciousness).

NOTE: Subjects suffering from ischemical heart disease may fall prey to angina pectoris, as a result even of a small increase in $\mathrm{CO}$ in the air, causing a $\mathrm{COHb}$ increase from $0.8 \%$ (physiological value) to three times the value.

Sulfur dioxide and sulfur trioxide have an irritating effect at higher concentrations. Foggy weather and an increased quantity of dust, soot and fly ash in the atmosphere make the situation worse, due to absorption of $\mathrm{SO}_{2}$ and $\mathrm{SO}_{3}$ by these particles: the result is the increased irritation of the breathing passages. Higher $\mathrm{SO}_{2}$ concentrations produce damage (etching) to the breathing pathways. This is cause why smoke disasters lead to increasing morbidity and mortality. Sulfur oxides of higher concentrations also damage vegetation and inorganic materials.

Nitrogen oxides are irritant agents (especially $\mathrm{NO}_{2}$ ) and probably decrease the immunity of the human body. Bound up with hemoglobin they produce methemoglobin, which is dangerous especially for babies (their livers are not able to remove it) but not so dangerous for them as water containing nitrates. Nitrogen oxides play a decisive role in photo- chemical reactions producing ozone and peroxoacetylnitrates (PANs) which, besides direct toxicity for breathing organs, stimulate the inception of cancer.

Epidemiological studies in UK prove that there is a higher rate of upper breathing pathway illnesses in pre-school children living in apartments with gas cookers than in those living in apartments with electric cookers. An increase by $30 \mu \mathrm{g} / \mathrm{m}^{3}$ (16 ppb) in $\mathrm{NO}_{2}$ concentration can over a period of time, lead to a $20 \%$ increase in respiration illness among children. Gas cookers should therefore be fitted with exhaust hoods.

Exhaust fumes from diesel engines produce in addition to $\mathrm{NO}_{\mathrm{x}}$ and other toxic agents, 3-nitrobenzatrone, which is the most carcinogenic agent discovered so far. It produces more mutations than 1.6 dinitropyrene, which was previously thought to be the most dangerous. Despite the low concentration of these agents in exhaust fumes, more serious limits are imposed for overloaded trucks at present because the greater the overloading, the greater the exhaust fumes.

Ozone irritates eyes and the delicate membranes of the lungs, causing inflammations with many symptoms, e.g., pains in the lungs, coughing, irritation of the throat. People who go in for jogging get tired rapidly, and building workers show a tendency to suffer from many colds. Sensitive people show the first impacts at an ozone concentration of 10 to $20 \mathrm{ppb}$ (20 to $40 \mu \mathrm{g} / \mathrm{m}^{3}$ ) (the bad smell also has an impact). First symptoms, e.g., headaches and other difficulties, start to appear at about $50 \mathrm{ppb}\left(100 \mu \mathrm{g} / \mathrm{m}^{3}\right)$.

Itching of the mucosis, increased breathing difficulties, decreasing physical performance and increased tiredness start from $100 \mathrm{ppb}\left(200 \mu \mathrm{g} / \mathrm{m}^{3}\right)$. According to research results, intensive outdoor activities should be cancelled when average ozone concentrations over a period three hours reach a level of $150 \mathrm{ppb}\left(300 \mu \mathrm{g} / \mathrm{m}^{3}\right)$.

Ozone is dangerous at effective bactericidal and deodorant concentrations, i.e., between 150 and 250 ppb (300 to 490 $\left.\mu \mathrm{g} / \mathrm{m}^{3}\right)$. These concentrations can threaten the function of the lungs, especially of children: there is evidence of lung damage after 16 to 20 hours exposure at a concentration of $120 \mathrm{ppb}$ $\left(240 \mu \mathrm{g} / \mathrm{m}^{3}\right)$. Ozone also decreases the resistance of the lungs to infection, and can stimulate an asthmatic attack. Ozone concentration exceeding $9000 \mathrm{ppb}\left(17700 \mu \mathrm{g} / \mathrm{m}^{3}\right)$ can cause an acute lung swelling followed by total change in the organism (bleeding, loos of weight, death).

Ozone is also dangerous for plants, especially for conifers, while deciduous trees are more resistant. Plants that are very sensitive to ozone: onions, oats, barley, tomatoes, alfalfa, clover, tobacco, beans, raldishes, spinach, potatoes, wheat and corn. A decrease in yield and quality, appearance, flavor, durability and composition changes have been found in these plants. A decrease in yield up to $60 \%$ occurs in grapes and citrous fruits.

Formaldehyde is a powerful irritant of the eye mucosis and the upper breathing pathways. It can be perceived at a concentration of about $400 \mu \mathrm{g} / \mathrm{m}^{3}$. Concentrations of 200 to $300 \mu \mathrm{g} / \mathrm{m}^{3}$ are tolerable, 400 to $500 \mu \mathrm{g} / \mathrm{m}^{3}$ produces powerful coughing, and concentrations over $10000 \mu \mathrm{g} / \mathrm{m}^{3}$ are bearable only for a few minutes.

There is evidence of higher formaldehyde concentration in new buildings. For this reason there are different pre- 
scribed values for new and old buildings in some regulations (e.g., the Finnish Standard on Indoor Climate and Building Ventilation prescribes an admissible formaldehyde concentration for new buildings of $1150 \mu \mathrm{g} / \mathrm{m}^{3}$, and for existing buildings of $800 \mu \mathrm{g} / \mathrm{m}^{3}$ ).

Part of the population is allergic to formaldehyde. This may be inborn or acquired due to frequent contact with formaldehyde. Two types of this allergy are known: dermatic and bronchial. Formaldehyde dries the skin, decreases immunity and is thought to produce cancer. It affects the menstrual cycle, causes pregnancy disorders and lowers the weight of newborn children. It is toxic at concentrations unbearable for humans, causing great irritation to the eyes and to the breathing passages.

Tobacco smoke not only produces a bad smell (see chapter about odor microclimate). It also threatens the human organism with carcinogenic components at higher, long-term concentrations: 3, 4 benzpyrene, hydrazine, vinilchloride, polycyclic aromatic hydrocarbons, arsenic, nickel, chromium, tar and nicotine, nornicotine, myosine and anatasine. Carbon monoxide, creating carboxyhemoglobin in the blood, increases from an original value of $1 \%$ to up $15 \%$ in the blood of smokers. Some irritating agents are also produced by smoking: formaldehyde, acetaldehyde, acrolein, acetone, nitrogen oxides and sulfane [9].

These toxic agents damage the mucosis of the upper breathing pathways, which lose the use of their cilia as a filter (rhythmic motions remove excessive mucus, trapped dust particles and other pollutants). This leads to multiplication of the cells producing mucus, and the typical smoker's cough appears at the same time (especially in the morning) replacing the function of the cilia (Fig. 3, [11]). Connective tissue in the lungs is multiplied at the same time, the bronchi are deformed (scarred) and contracted. Contracted locations are followed by dilations of the breathing pathways, and the effective area for gaseous exchange is decreased. The result is emphysema which makes breathing difficult. Larger bronchi, chronically irritated, respond by decreasing their diameter and by mucosis swelling. Chronic obstructive bronchitis develops; the patient begins to suffocate.

Immunity of the organism decreases, thus enabling the formation of lung cancer. This is the most frequent type of tumor in males and even females in many countries.
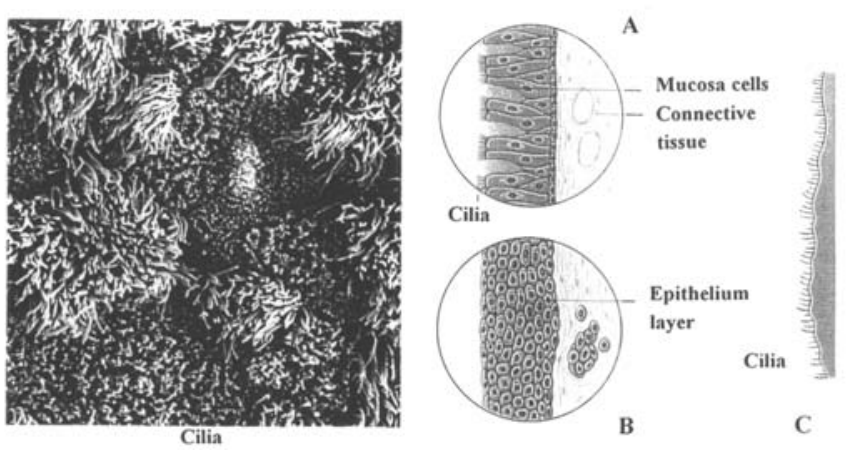

Fig. 3: The origin of smoker's morning cough (A mucosis within the cilia of a non-smoker, B smoker's mucosis without cilia, C cilia of a non-smoker).

The cardiovascular system (heart and vessels) is also seriously threatened. Smoking is the riskiest factor for ischemic disease of the heart (heart attack) and legs, and for arterosclerosis. Smokers suffer more frequently from stomach and duodenal ulcers, from cancer of the urinary bladder, and diseases of the mouth, tonque, pharynx and throat. Female smokers give birth to babies of lower weight, i.e., they are born prematurely [9].

It has been shown that the probability of a smoker dying after smoking 200000 cigarettes is eleven times higher than that of a non-smoker. However, non-smoker's can also be threatened in the same way if exposed to other people's cigarette smoke, because they are more sensitive to the smoke.

A ten-year research project at Harvard University (Boston, U.S.A.) (32 thousand healthy non-smoking women aged 36 to 61 years) ascertained that regular non-smokers staying in rooms filled with smoke increase their risk of heart diseases twofold. It has also been found that willing, active smoking affects the lungs more negatively than the cardiovascular system, but that passive, unwilling smoking, on the contrary, threatens the cardiovascular system more than the lungs.

\section{Admissible Limits of Toxic Gases}

Some examples of the admissible concentrations of certain toxic substances in the outdoor air are presented in Table 2.

Table 2: Admissible concentrations of some toxic substances in outdoor air (Environmental Quality, The $3^{\text {rd }}$ Annual Report of The Council on Environmental Quality, Washington, D.C. 20402, 1972)

\begin{tabular}{|c|c|c|c|}
\hline Air pollutant & Sampling time & p.p.m. & Admissible concentration $\mu \mathrm{g} / \mathrm{m}^{3}$ \\
\hline \multirow[t]{2}{*}{ Carbon monoxide } & 1 hour & 35 & 40000 \\
\hline & 8 hour & 9 & 10000 \\
\hline \multirow[t]{3}{*}{ Sulfur dioxide } & 3 hour & 0.5 & $1.300 \mathrm{mg}$ \\
\hline & 24 hour & 0.1 & $0.260 \mathrm{mg}$ \\
\hline & mean per year & 0.02 & $0.060 \mathrm{mg}$ \\
\hline \multirow[t]{2}{*}{ Aerosol } & 24 hour & & 150 \\
\hline & geometric mean per year & & 60 \\
\hline Nitrogen dioxide & mean per year & 0.05 & 100 \\
\hline \multirow[t]{2}{*}{ Photochemical oxidative agents } & 1 hour & 0.08 & 160 \\
\hline & & & $\mathrm{SO}_{2} \mathrm{Ka}=260$ \\
\hline
\end{tabular}


Admissible limits of toxic gases for a building interior should be slighter higher than those prescribed for outdoors. However, they should be lower than those prescribed for workplaces.

E.g., Austrian Standard H 6000t3 (January 1989) prescribes that the admissible value for a building interior should be $10 \%$ of the highest admissible value for workplaces.

According to WHO (World Health Organization) (WHO Regional Publications, European Series No. 23, 1987) guideline values for indoor pollution have been prescribed (see Table 3); no guidance is given on outdoor concentrations that might be of indirect relevance.

Acceptable limits for outdoor ozone were introduced by the European Union in 1994: $110 \mu \mathrm{g} / \mathrm{m}^{3}$ (8-hour average value, so-called protection threshold) (irritation of eyes and breathing passages), $180 \mu \mathrm{g} / \mathrm{m}^{3}$ (one hour average value, so-called public information threshold) (inhabitants must be informed because children playing outdoors must be limited to max. one hour, loos of concentration can occur in adults. Adult sporting activities outdoors should also be limited). There is also a limit of $360 \mu \mathrm{g} / \mathrm{m}^{3}$ (also a one-hour average value, the so-called warning limit) (inhabitants must be warned).

Removal of harmful agents from various products also plays an important role in air pollution control. The quality level of products from this point of view is expressed by so-called Eco-labelling, which started in Germany in 1978 when the so-called Blue Angel mark was introduced (see Fig. 4). For an example of prescribed values, see Table 4.

Table 3: Guideline Values for Individual Substances Based on Effects other than Cancer or Odour/Annoyance ${ }^{\mathrm{a}}$ (Guidelines for Ventilation Requirements in Buildings. EUR 14449 EN. Brussels-Luxemburg, 1992).

\begin{tabular}{|c|c|c|c|}
\hline Substance & Time-weighted average & Averaging time & Chapter \\
\hline \multirow[t]{2}{*}{ Cadmium } & $1-5 \mathrm{ng} / \mathrm{m}^{3}$ & 1 year (rural areas) & \multirow[t]{2}{*}{19} \\
\hline & $10-20 \mathrm{ng} / \mathrm{m}^{3}$ & 1 year (urban areas) & \\
\hline Carbon disulfide & $100 \mu \mathrm{g} / \mathrm{m}^{3}$ & 24 hours & 7 \\
\hline \multirow[t]{4}{*}{ Carbon monoxide } & $100 \mathrm{mg} / \mathrm{m}^{3 \mathrm{~b}}$ & 15 minutes & \multirow[t]{4}{*}{20} \\
\hline & $60 \mathrm{mg} / \mathrm{m}^{3 \mathrm{~b}}$ & 30 minutes & \\
\hline & $30 \mathrm{mg} / \mathrm{m}^{3 \mathrm{~b}}$ & 1 hour & \\
\hline & $10 \mathrm{mg} / \mathrm{m}^{3}$ & 8 hours & \\
\hline 1,2-Dichloroethane & $0.7 \mathrm{mg} / \mathrm{m}^{3}$ & 24 hours & 8 \\
\hline Dichloromethane (Methylene chloride) & $3 \mathrm{mg} / \mathrm{m}^{3}$ & 24 hours & 9 \\
\hline Formaldehyde & $100 \mu \mathrm{g} / \mathrm{m}^{3}$ & 30 minutes & 10 \\
\hline Hydrogen sulfide & $150 \mu \mathrm{g} / \mathrm{m}^{3}$ & 24 hours & 22 \\
\hline Lead & $0.5-1.0 \mu \mathrm{g} / \mathrm{m}^{3}$ & 1 year & 23 \\
\hline Manganese & $1 \mu \mathrm{g} / \mathrm{m}^{3}$ & 1 year $^{c}$ & 24 \\
\hline Mercury & $1 \mu \mathrm{g} / \mathrm{m}^{3 \mathrm{~d}}$ (indoor air) & 1 year & 25 \\
\hline \multirow[t]{2}{*}{ Nitrogen dioxide } & $400 \mu \mathrm{g} / \mathrm{m}^{3}$ & 1 hour & \multirow[t]{2}{*}{27} \\
\hline & $150 \mu \mathrm{g} / \mathrm{m}^{3}$ & 24 hours & \\
\hline \multirow[t]{2}{*}{ Ozone } & $150-200 \mu \mathrm{g} / \mathrm{m}^{3}$ & 1 hour & \multirow[t]{2}{*}{28} \\
\hline & $100-120 \mu \mathrm{g} / \mathrm{m}^{3}$ & 8 hours & \\
\hline Styrene & $800 \mu \mathrm{g} / \mathrm{m}^{3}$ & 24 hours & 12 \\
\hline \multirow[t]{2}{*}{ Sulfur dioxide } & $500 \mu \mathrm{g} / \mathrm{m}^{3}$ & 10 minutes & \multirow[t]{2}{*}{30} \\
\hline & $350 \mu \mathrm{g} / \mathrm{m}^{3}$ & 1 hour & \\
\hline Sulfuric acid & $-{ }^{\mathrm{e}}$ & - & 30 \\
\hline Tetrachloroethylene & $5 \mathrm{mg} / \mathrm{m}^{3}$ & 24 hours & 13 \\
\hline Toluene & $8 \mathrm{mg} / \mathrm{m}^{3}$ & 24 hours & 14 \\
\hline Trichloroethylene & $1 \mathrm{mg} / \mathrm{m}^{3}$ & 24 hours & 15 \\
\hline Vanadium & $1 \mu \mathrm{g} / \mathrm{m}^{3}$ & 24 hours & 31 \\
\hline
\end{tabular}

${ }^{a}$ Information from this table should not be used without reference to the rationale given in the chapters indicated

${ }^{\mathrm{b}}$ Exposure at these concentrations should be for no longer than the indicated times and should not be repeated within 8 hours

${ }^{\mathrm{c}}$ Due to respiratory irritancy, it would be desirable to have a short-term guideline, but the present data base does not permit such estimations

${ }^{d}$ The guideline value is given only for indoor pollution: no guidance is given on outdoor concentrations (via deposition and entry into the food chain) that might be of indirect relevance 
NOTE: When air levels in the general environment are orders of magnitude lower than the guideline values, present exposures are unlikely to present a health concern. Guideline values in those cases are directed only to specific release episodes or specific indoor pollution problems.

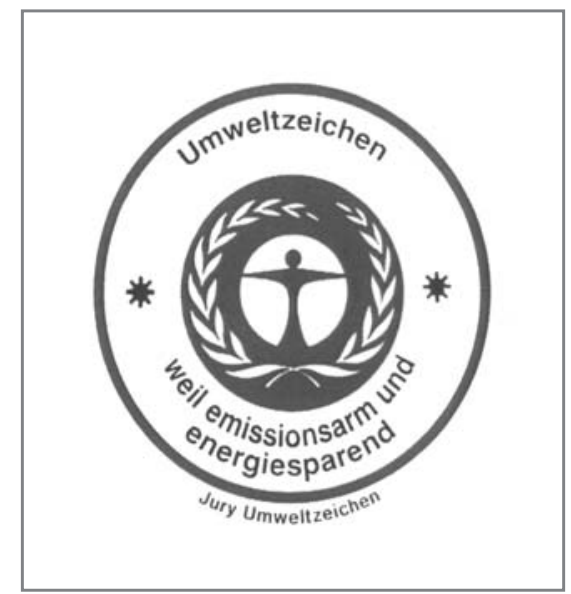

Fig. 4: German Eco-label, the so called Blue Angel

Table 4: Acceptable Limits for Heating Boilers up to $350 \mathrm{~kW}$ according to German Regulations

\begin{tabular}{|l|c|c|c|}
\hline & & DIN 470211 & Blue Angel \\
\hline $\begin{array}{l}\text { Boilers } \\
\text { with atmospheric } \\
\text { burners, natural gas }\end{array}$ & $\mathrm{NO}$ & $50 \mathrm{mg} / \mathrm{kWh}$ & $70 \mathrm{mg} / \mathrm{kWh}$ \\
\cline { 2 - 4 } & $\mathrm{CO}$ & $100 \mathrm{mg} / / \mathrm{kWh}$ & $60 \mathrm{mg} / \mathrm{kWh}$ \\
\hline \multirow{2}{*}{ Oil boiler } & $\mathrm{NO}_{\mathrm{x}}$ & $260 \mathrm{mg} / \mathrm{kWh}$ & $120 \mathrm{mg} / \mathrm{kWh}$ \\
\cline { 2 - 4 } & $\mathrm{CO}$ & $110 \mathrm{mg} / \mathrm{kWh}$ & $60 \mathrm{mg} / \mathrm{kWh}$ \\
\hline
\end{tabular}

The system of Eco-labelling was introduced throughout the European Union in 1992 by EU Directive No. 880/1992 with the mark of the EU sign over a flower (Fig. 5).

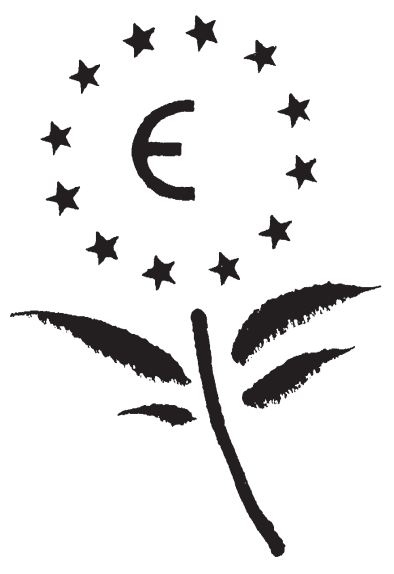

Fig. 5: European Eco-label

Carpeting, owing to its large area, usually causes the most ifficult problems within an interior. For this reason, a special Eco-label (Fig. 6) was introduced for carpets by a German Research Institute for Carpets (Deutsches Teppich
Forschungsinstitut e.V.). The label is a guarantee that the labeled carpet is acceptable from the indoor air pollution point of view.

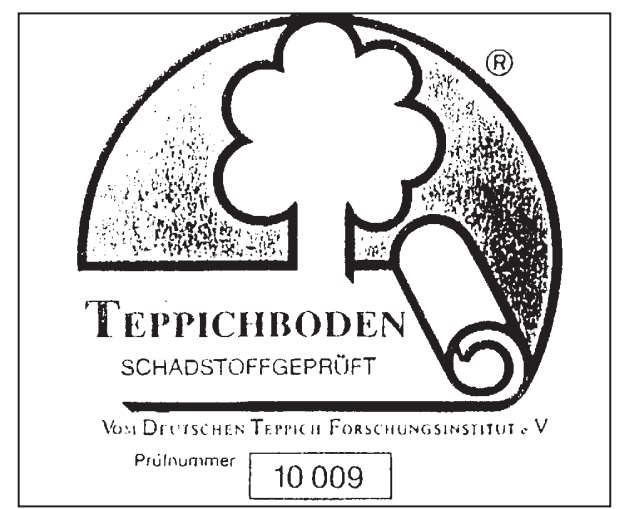

Fig. 6: Eco-label for carpets

The aim of Eco-labelling is first to provide a guarantee that every labeled product is acceptable from indoor air pollution point of view, and second to assist the selection and purchase of an environment-friendly product.

\section{Removal of Toxic Gases}

Harmful gases can be removed from a building interior by suitable changes in

a) the source of toxic substances,

b) the environment,

c) human activities and human attitudes.

\subsection{Changes in the Source of Toxic Substances}

Reducing or even removing the source of toxic substances is the most effective way of optimization. Building materials that do not release toxic agents should be preferred. Technologies with minimal sources of toxic substances should be used in industry. Boilers, stoves and ranges should be cleaned regularly when complete combustion is reached.

Indoor air quality can also sometimes be improved quite simply. For example, by using soda saleratus or a mixture of on e part flour and one part plaster (calcinated gypsum) instead of harmful insecticide aerosols to kill cockroaches.

Improvements in the efficiency of combustion engines have led to a decrease in the toxic substances that they produce. Because combustion with an excessive amount of air increases $\mathrm{NO}_{\mathrm{x}}$ production, an additive called Carbonex has been developed to reduce the production of smog, soot and $\mathrm{NO}_{\mathrm{x}}$. Carbonex dissolves iron in organic liquids, e.g. oil or gasoline. Carbonex is sprayed into the flame simultaneously with the coal or other fuel based on carbon. Combustion is impacted in two ways: a) particles are more rapidly oxidized and can thus burn better, $b$ ) the process can be accomplished at lower temperatures. Additives applied in diesel engines reduce emissions by $43 \%$, and efficiency increases by 1.5 to $3 \%$. In oil burners, emissions decrease by $67 \%$, and in stone coal combustion $\mathrm{NO}_{\mathrm{x}}$ emissions decrease by $25 \%$.

However, the most effective changes in the source of toxic substances are and will be: more rational use of energy, use of cleaner fuels, and the development of non-combustion technologies. 
More rational use of energy seems to be the most effective, because conserved energy is the cheapest energy. The possibilities are great. E.g., the U.S.A. spent $10 \%$ of its gross national product on fuels in 1986, as against only $4 \%$ in Japan at the same time. It has been proved in the U.S.A. that each investment of two cents in more economic energy technologies saves one $\mathrm{kWh}$ of electric current. Motor cars provide an example. Since 1973 the fuel efficiency of new cars has increased on average by $25 \%$, and is still growing (the latest Citroen has fuel consumption of 3.51 of gasoline per $100 \mathrm{~km}$, and the Toyota AVX has a consumption of 2.211 of diesel per $100 \mathrm{~km}$ ). The efficiency of oil boilers has increased from 0.65 to 0.86 , natural gas boilers from 0.65 to $0.87-1.0$, newly developed freezers and refrigerators in the U.S.A. consume only $15 \%$ of the consumption of present models. The use of an $18 \mathrm{~W}$ fluorescent lamp instead of a $75 \mathrm{~W}$ electric bulb (with the same illumination output) saves $200 \mathrm{~kg}$ of coal in an electrical power plant over a period of ten years, etc. An indication of the future potential is the following fact: the economy of the U.S.A. increased by one third between 1973 and 1986, without an increase in energy consumption.

Another possibility is to increase the use of natural gas, which is available in abundance. It produces $30 \%$ less $\mathrm{CO}_{2}$ during combustion than cruide oil, and $40 \%$ less than coal; emissions of $\mathrm{NO}_{\mathrm{x}}$ and $\mathrm{SO}_{\mathrm{x}}$ are also significantly reduced.

Sulphur emissions from coal burning can also be reduced by changing to so-called liquid coal, which is a mixture of water, powder coal and special chemicals. It is produced by Svenska Fluidcarbon in Malmö, and is $30 \%$ cheaper than heating oil.

Nuclear power plants use a typical progressive technology without combustion (even if there are some problems with safety and with spent radioactive fuels) and also siliceous photovoltaic cells, which have come down in price from 44 $\mathrm{USD} / \mathrm{W}$ in 1976 to $1.6-4.0 \mathrm{USD} / \mathrm{W}$ in 1988 , and are still falling.

\subsection{Dealing with Toxic Substances in a Building}

Toxic substances in a building can be dealt with in the following ways:

a) stop the substance from spreading within the building,

b) adequate air change, i.e., suitable ventilation,

c) air filtration,

d) decay of toxic substances into non-toxic substances, and

e) remove of the substance by air ionization.

\subsubsection{How to stop toxic substances from spreading inside a building}

Toxic substances can be stopped from spreading inside a building either by separating vertical shafts into several parts (we must be careful about the air streams produced by infiltration and by indoor heat sources), or by locating harmful sources on the highest floors.

The former arrangement is important in multistorey buildings, especially where toxic substances can be spread by upward pressure. E.g., if the staircase is a single shaft, upward pressure works and the substances will be lifted upward and all over the building from a source in the lower part of the building.

\subsubsection{Adequate air change - ventilation}

Ventilation is preferred in most cases, owing to its simplicity and effectiveness.

The quantity of outdoor air supplied into the interior depends on the admissible concentration, expressed by the equation

$$
\dot{V}=\frac{\dot{m}}{\rho_{\max }-\rho_{\mathrm{o}}}\left[\mathrm{m}^{3} \cdot \mathrm{h}^{-1}\right]
$$

where

$\dot{V}=$ outdoor air volume rate necessary for admissible concentration maintenance $\left[\mathrm{m}^{3} \cdot \mathrm{h}^{-1}\right]$

$\dot{m}=$ quantity of the arising toxic agent $\left[\mathrm{g} \cdot \mathrm{h}^{-1}\right]$

$\rho_{\max }=\quad$ highest admissible concentration as prescribed by standards $\left[\mathrm{g} \cdot \mathrm{m}^{-3}\right]$

$\rho_{\mathrm{o}}=$ concentration of the toxic agent in outdoor air $\left[\mathrm{g} \cdot \mathrm{m}^{-3}\right]$

If a person is exposed to several toxic agents at the same time, the outdoor air volume rate should be estimated for each agent separately and then

a) the sum of all values is used if the impact of all agents on humans is also summed, and

b) the highest value is used if the effect of each agent on humans is independent.

\subsubsection{Filtration}

Filtration can be performed by activated coal or by charcoal, which do not absorb humidity (up to relative air humidity $75 \%$ ) and do not change the chemical composition of the air. The filtration efficiency depends on the contact period of agent and coal. The minimum coal thickness layer is $3 \mathrm{~cm}$ for air velocity of 2.5 to $3.0 \mathrm{~m} / \mathrm{s}$ and efficiency of $80 \%$.

Filtration is used

a) for outdoor air supplied into the building (only special rooms: food industry, pharmaceutical plants),

b) tin recirculated air (in ventilation, heating, and air conditioning systems) usually, and

c) tin extracted air (when there is a threat of outdoor air pollution).

\subsubsection{The Decay of Toxic Substances into Nontoxic Substances}

A grown tree of Aesculus hippocastanum (a sort of chestnut tree) is able to clean a volume of $20000 \mathrm{~m}^{3}$ (e.g., $10 \mathrm{~m}$ high, $20 \mathrm{~m}$ wide, $100 \mathrm{~m}$ long) of motor-car exhaust smoke, without itself being affected by the smoke, according research carried out at the University of Stockholm. The substances entering the tree are consumed by the microorganisms on its roots and within the root space according to NASA research. Not only can the quality of outdoor air be improved in this way, but also the quality of fresh air supplied into the interior can improve.

\subsubsection{Removal of Toxics by Intensive Air Ionization}

Formaldehyde, $\mathrm{SO}_{2}$ and dioxin can be successfully removed by intensive air ionization. For this purpose an ionizer (producing negative aeroions) with a fan (ensuring proper air 


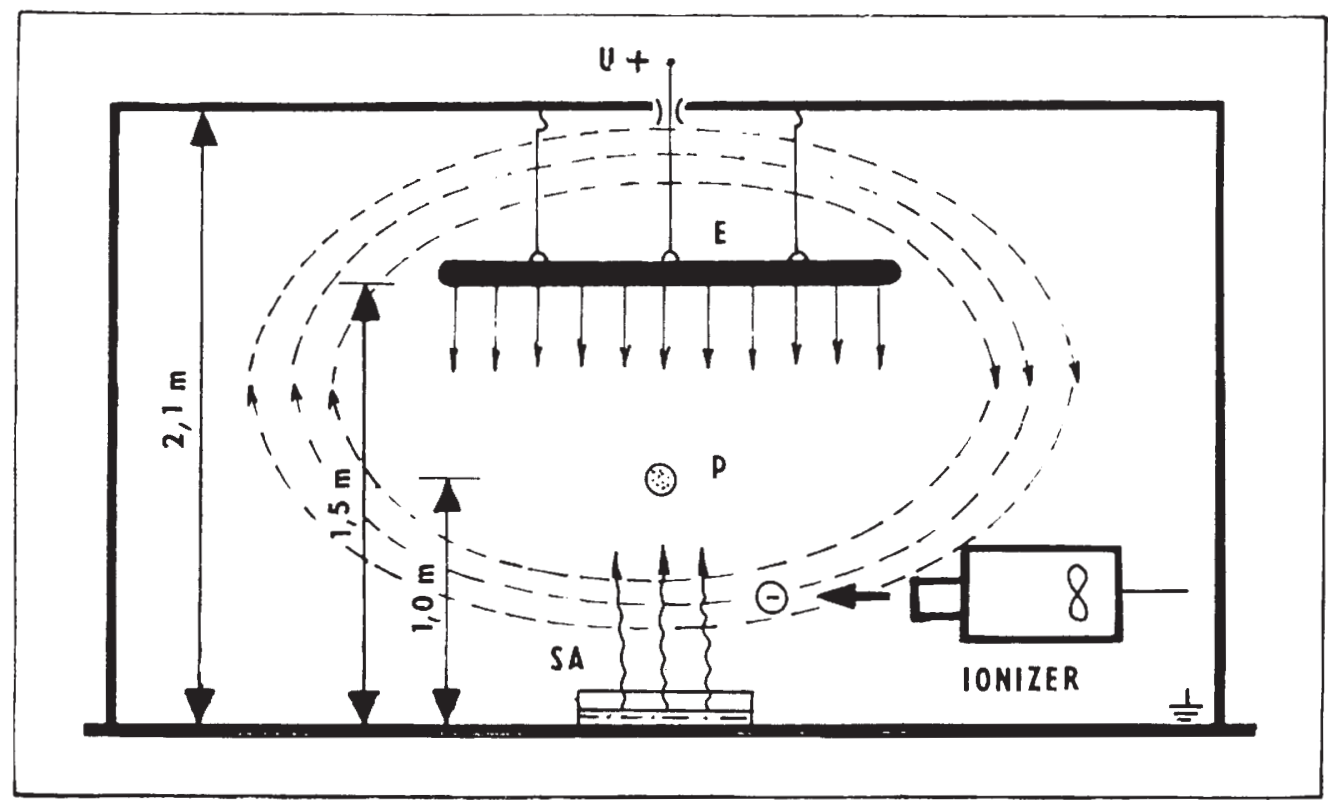

Fig. 7: Scheme of an arrangement with intensive air ionization for removal of toxic substances from an interior (E positive electrode, SA source of toxics, $\mathrm{P}$ probe for toxic concentration estimation)

streaming within the room) and an electrode connected to the positive pole of a direct current source are applied (Fig. 7). The formaldehyde content in a room decreases by $80 \%$ within 30 minutes of operation and the $\mathrm{SO}_{2}$ content by $73 \%$.

\subsection{Gas Masks}

A gas mask can also be used for protection against toxics, but it is suitable only in special, exceptional situations.

\section{References}

[1] EUR 14449 EN. Guidelines for Ventilation Requirements in Buildings. Report No. II. Commision of EC, Luxemburg, 1992.

[2] Holcátová, I., Bencko, V.: Health aspects of formaldehyde in the indoor environment. Centr. eur. J. publ., 1997, Vol. 5, No. 1, p. 38-41.

[3] Jokl, M. V.: Microenvironment: The Theory and Practice of Indoor Climate. Springfield (Illinois - U.S.A.): Thomas Publisher, 1989, p. 416.

[4] Jokl, M. V.: Evaluation of indoor air quality using the decibel concept. Int. J. of Environmental Health Research, 1997, Vol. 7, No. 4, p. 289-306.

[5] Jokl, M. V.: New units for indoor air quality: decicarbdiox and decitvoc. International Journal of Biometeorology, 1998, Vol. 42, No. 2, p. 93-111.
[6] Jokl, M. V.: Evaluation of indoor air quality using the decibel concept based on carbon dioxide and TVOC. Building and Environment, 2000, Vol. 35, No. 8, p. 677-697.

[7] Jokl, M. V.: Toxic gases within building interior. In Czech. Part 1. Interiér stavby, 2000, Vol. 3, No. 11, p. 57-58.

[8] Jokl, M. V.: Toxic gases within building interior. In Czech. Part 2. Interiér stavby, 2000, Vol. 3, No. 12, p. 48-49.

[9] Kašák, V.: How to survive smog. In Czech. MAXDORF, edice MEDICA - Praktické rady lékaře sv. 6, Praha 1995, p. 61.

[10] Symon, K., Bencko, V. et al: Air Pollution and Health. In Czech. Praha: Avicenum, 1988.

[11] The Human Body. Bratislava: GEMINI Ltd., 1992.

Miloslav V. Jokl, Ph.D., Sc.D, University Professor phone: +420224354432

fax: +420233339961

e-mail: miloslav.jokl@fsv.cvut.cz

Czech Technical University in Prague

Faculty of Civil Engineering

Thákurova 7

16629 Prague 6, Czech Republic 